\title{
Screening for FMR1 CGG Repeat Expansion in Thai Patients with Autism Spectrum Disorder
}

\author{
Areerat Hnoonual $\mathbb{D}^{1}$, Charunee Jankittunpaiboon $\mathbb{D}^{2},{ }^{2}$ and Pornprot Limprasert $\mathbb{D}^{1,3}$ \\ ${ }^{1}$ Department of Pathology, Faculty of Medicine, Prince of Songkla University, Songkhla 90110, Thailand \\ ${ }^{2}$ Office of Scientific Instrument and Testing, Prince of Songkla University, Songkhla 90110, Thailand \\ ${ }^{3}$ Faculty of Medicine, Siam University, Bangkok 10160, Thailand
}

Correspondence should be addressed to Pornprot Limprasert; lpornpro@yahoo.com

Received 30 August 2021; Revised 7 November 2021; Accepted 26 November 2021; Published 8 December 2021

Academic Editor: Davor Zeljezic

Copyright (c) 2021 Areerat Hnoonual et al. This is an open access article distributed under the Creative Commons Attribution License, which permits unrestricted use, distribution, and reproduction in any medium, provided the original work is properly cited.

\begin{abstract}
Autism spectrum disorder (ASD) is a complex disorder with a heterogeneous etiology. Fragile X syndrome (FXS) is recognized as the most common single gene mutation associated with ASD. FXS patients show some autistic behaviors and may be difficult to distinguish at a young age from autistic children. However, there have been no published reports on the prevalence of FXS in ASD patients in Thailand. In this study, we present a pilot study to analyze the CGG repeat sizes of the FMR1 gene in Thai autistic patients. We screened 202 unrelated Thai patients (168 males and 34 females) with nonsyndromic ASD and 212 normal controls using standard FXS molecular diagnosis techniques. The distributions of FMR1 CGG repeat sizes in the ASD and normal control groups were similar, with the two most common alleles having 29 and 30 CGG repeats, followed by an allele with 36 CGG repeats. No FMR1 full mutations or premutations were found in either ASD individuals or the normal controls. Interestingly, three ASD male patients with high normal CGG and intermediate CGG repeats (44, 46, and 53 CGG repeats) were identified, indicating that the prevalence of FMR1 intermediate alleles in Thai ASD patients was approximately $1 \%$ while these alleles were absent in the normal male controls. Our study indicates that CGG repeat expansions of the FMR1 gene may not be a common genetic cause of nonsyndromic ASD in Thai patients. However, further studies for mutations other than the CGG expansion in the FMR1 gene are required to get a better information on FXS prevalence in Thai ASD patients.
\end{abstract}

\section{Introduction}

Autism spectrum disorder (ASD) is a complex neurodevelopmental disorder characterized by deficits in social interactions and social communications, as well as restricted interests and stereotyped and repetitive behaviors. In recent years, an increase in the apparent prevalence of autism has been reported worldwide. The prevalence of ASD was estimated to be 1 in 54 children in a recent study, with a $4: 1$ ratio of affected males to females [1]. The diagnosis of ASD is primarily based on medical assessment, behavioral evaluations, and the application of the autism criteria enumerated in the Diagnostic and Statistical Manual of Mental Disorders (DSM-5). The causes of ASD remain largely unknown, but an earlier study in twins reported a consistently high genetic contribution to ASD [2]. It is generally thought that ASD is likely explained by a multifactorial etiology which includes various inherited factors, genetic mutations, and environmental factors. About $10-20 \%$ of ASD cases have been identified as having a genetic disorder caused by chromosomal aberrations and single gene mutations, including fragile $\mathrm{X}$ syndrome, tuberous sclerosis, and Rett syndrome. More than 100 ASD-risk genes carrying mutations have been identified in ASD [3-8]; therefore, genetic testing is indicated in the medical workup for individuals with ASD, which may include G-banded karyotyping, fragile $\mathrm{X}$ testing, chromosomal microarray, and/or whole exome sequencing $[5,9]$.

Fragile X syndrome (FXS) is the most frequent monogenic cause of intellectual disability (ID) and ASD. FXS is caused by expansion of CGG repeats in the $5^{\prime}$ untranslated region of the fragile $\mathrm{X}$ mental retardation 1 gene (FMR1), 
which is located on chromosome Xq27.3. It has been established that the normal CGG repeat number is below 45 and alleles in this repeat range are transmitted stably from generation to generation. The AGG intersperse the CGG repeat every 9 or 10 CGG repeats, reducing repeat instability [11,12]. CGG repeats between 55 and 200 are considered FMR1 premutation alleles, which are associated with maternal expansions of the number of CGGs in the next generation. More than 200 repeats result in a full mutation which gives rise to FXS. The majority of males who carry the full mutation FXS have mild to moderate ID, while about half of females with the full mutation have only normal or borderline intellectual function because of cellular mosaicism resulting from X-chromosome inactivation. As with most aspects of the FXS phenotype, behavioral phenotypes in FXS are quite variable and include attention deficits, hyperactivity, hyperarousal, aggression and self-injury, social anxiety, and autism [13, 14]. Some studies have reported that some behavioral symptoms of patients with FXS are similar to autistic patients and it is sometimes difficult to distinguish them from each other, especially in young children [15-18]. FXS is the most commonly known inherited single-gene cause of ASD, accounting for approximately $1-6 \%$ of all autistic cases $[5,9,17$, 19]. Over the past decade, many studies have evaluated the FXS-ASD link. In individuals with the full FXS mutations, up to $60 \%$ of males meet the diagnostic criteria for ASD and approximately $30-50 \%$ of males with FXS meet the full DSM-IV criteria for autism [17, 20-25]. Additionally, more than $90 \%$ of males with FXS display some autistic characteristics $[14,16,17]$. The percentage of autism is lower $(3-20 \%)$ in females with FXS [17, 21, 26, 27]. In recent years, changes in the diagnostic criteria for ASD from DSM-IV to DSM-5 have resulted in slightly changed incidence rates. Approximately $50 \%$ of males and $30 \%$ of females with FXS who met the full criteria for an ASD diagnosis using the DSM-IV also meet the DSM-5 criteria [28]. Although autistic features show high prevalences in FXS, the fact is that sometimes a patient will have no signs of the syndrome, therefore, all children affected by ASD, especially boys, should be tested for FMR1 mutations. Molecular screening for CGG repeat expansions of the FMR1 gene is now recommended for all individuals diagnosed with ASD due to the high levels of comorbidity between ASD and FXS and the variable expressiveness of FXS [9, 29-32]. Studies of FMR1 CGG repeats using DNA testing have found widely varying levels of abnormalities in the FMR1 gene [33-52], while some studies have found no abnormal FMR1 genes in patients with autism [53-56].

The widely varying findings of FXS frequency raise the question as to whether CGG repeat expansions of the FMR1 gene may not be a common cause in patients with ASD. Moreover, the rate of FMR1 full mutations identified among ASD cohorts is generally lower than that identified in ID cohorts $[43,55,57]$. In Thailand, one study of FXS frequencies in patients with ID and DD of unknown etiology found that the frequency of a full mutation was $6.8 \%(16 /$ 237) [58]; however, to date, there have been no studies on FXS mutations in Thai ASD patients. Therefore, the aim of this study was to analyze the CGG repeat sizes of the FMR1 gene in Thai patients with nonsyndromic ASD.

\section{Materials and Methods}

2.1. Study Cohort. A total of 202 patients with ASD (168 males and 34 females) were recruited from a cohort of 203 Thai children with nonsyndromic ASD, excluding one male patient with ring chromosome 13, reported in a previous study [59]. All patients had normal karyotypes. The mean ages in the male and female patients were 4.33 and 4.19 years, respectively. These patients met the diagnostic criteria for autistic disorder or pervasive developmental disordersnot otherwise specified (PDD-NOS) according to the DSM-IV using a clinical checklist [60]. Two hundred and twelve normal male controls were selected from a previous study [61] to compare CGG repeat distributions with ASD cases.

The study protocol was approved by the three Institutional Ethics Committees (EC 48/364-006, ID 05-49-24, and No.061/2548).

2.2. FXS DNA Analysis. All patients were screened for FXS using standard molecular methods according to the American College of Medical Genetics and Genomics (ACMG) Standards and Guidelines for fragile $\mathrm{X}$ testing [10, 30]. The lengths of the CGG repeats were determined through fluorescent PCR fragment analysis. The PCR reactions were performed in $10 \mu \mathrm{l}$ mixtures comprised of $25 \mathrm{ng}$ DNA, 1X PCR buffer, $1 \mathrm{mM} \mathrm{MgCl}_{2}, 200 \mu \mathrm{M}$ dNTPs (dGTP replaced with 7-deaza dGTP), $2.2 \mathrm{M}$ betaine, $0.2 \mu \mathrm{M}$ each of the primers FRAXA-PSU-F ( $5^{\prime}$-6FAM-CAGCGTTGATCACG TGACGTGGTTTCAGTG- $3^{\prime}$ ) and FRAXA-PSU-R ( $5^{\prime}$-GA TGGGGCCTGCCCTAGAGCCAAGTA-3 ${ }^{\prime}$ ), and 0.5 units of Hot Start Taq DNA Polymerase (Immolase, Bioline). The PCR reactions were carried out beginning with an initial hot start at $95^{\circ} \mathrm{C}$ for $10 \mathrm{~min}$, followed by 35 cycles of denaturation at $95^{\circ} \mathrm{C}$ for $1 \mathrm{~min}$, annealing at $66^{\circ} \mathrm{C}$ for $1 \mathrm{~min}$, extension at $72^{\circ} \mathrm{C}$ for 1 minute, and a final extension of $72^{\circ} \mathrm{C}$ for $10 \mathrm{~min}$. The PCR product was then mixed with $10 \mu \mathrm{l} \mathrm{HiDi}$ formamide and $0.2 \mu \mathrm{l} \mathrm{LIZ500,} \mathrm{then} \mathrm{denatured} \mathrm{at} 95^{\circ} \mathrm{C}$ for $2 \mathrm{~min}$ and $4^{\circ} \mathrm{C}$ for $5 \mathrm{~min}$. The PCR mixture was loaded on an ABI3130 Genetic Analyzer and analyzed using GeneMapper v3.2 software. To predict instability or expansion of FMR1 CGG repeat alleles, AGG interruptions were determined using FMR1 triplet repeat-primed PCR (TP-PCR) [62] in individuals carrying intermediate or premutation alleles and their mothers. The TP-PCR assay was used not only to identify AGG interruptions, but also resolves the difficulty of detecting mosaic males when using conventional/ fluorescent PCR because up to $\sim 10 \%$ of mosaicism can be detected by the TP-PCR method [63, 64]. Methylationspecific PCR was also performed in the study males to determine their methylation status based on the method used in a previous study [65].

2.3. Statistical Analysis. In the analysis, the samples were divided into 7 groups according to the identified common and uncommon FMR1 CGG repeats: 17-28, 29, 30, 31-35, 
TABLE 1: Comparison of CGG repeat groups between study ASD male cases and male controls.

\begin{tabular}{lcccc}
\hline \multirow{2}{*}{ CGG repeats } & \multicolumn{2}{c}{ ASD males } & \multicolumn{2}{c}{ Male controls } \\
& Number & Percentage & Number & Percentage \\
\hline $17-28$ & 11 & 6.55 & 22 & 10.38 \\
29 & 84 & 50.00 & 111 & 52.36 \\
30 & 41 & 24.40 & 42 & 19.81 \\
$31-35$ & 10 & 5.95 & 15 & 7.08 \\
36 & 15 & 8.93 & 15 & 7.08 \\
$37-40$ & 4 & 2.38 & 6 & 2.83 \\
$41-54$ & $3^{*}$ & 1.79 & $1^{* *}$ & 0.47 \\
Total & 168 & 100 & 212 & 100 \\
\hline
\end{tabular}

${ }^{*} 44,46$, and 53 CGG repeats; ${ }^{* *} 41$ CGG repeats. Chi - square $=4.787, \mathrm{df}$ $=6, P=0.5714$ (no statistically significant differences).

36, 37-40, and 41-54 (high normal and intermediate alleles). Chi-square test was used to test for differences in allele distributions between the ASD and normal control groups. Fisher's exact test was used to compare the high and intermediate alleles (41-54 CGG repeats) between the ASD and control groups.

\section{Results}

Molecular screening of FXS in the study patients with ASD revealed CGG repeats in the normal ( $<45$ CGG repeats) or intermediate (45-54 CGG repeats) range in all ASD males (Table 1) and females (Supplementary Table 1). The allele distributions in the ASD male patients ranged from 18 to 53 CGG repeats (20 alleles) compared to 17-41 CGG repeats ( 24 alleles) in the male controls. Although the allele numbers in the male cases were smaller than in the male controls, the heterozygosity of alleles in the ASD male cases (0.6799) was slightly greater than that in the male controls (0.6787). Regarding the distribution of the CGG repeats, 29 and 30 repeats were the most common numbers of repeats, accounting for $50.00 \%$ and $24.40 \%$ of our ASD cases, respectively, with 36 repeats making up a further $8.93 \%$ of male ASD cases. Similarly, in the normal control group, the two most common alleles were 29 $(52.36 \%)$ and 30 CGG repeats (19.81\%), followed by 36 CGG repeats (7.08\%) (Table 1 and Figure 1).

The allele distributions, based on the 7 groups of identified CGG repeats, between the ASD male cases and the male controls, were not statistically significantly different (chi - square $=4.787, \mathrm{df}=6, P=0.5714$, Table 1$)$. All normal controls had FMR1 CGG repeats in the normal range of less than or equal to 41 repeats. Interestingly, 3 male ASD patients showed high normal or intermediate CGG allele repeats of 44,46 , and 53 CGG repeats, transmitted from their mothers (Supplementary Figure 1), while these alleles were absent in the male controls. Methylation-specific PCR testing of these 3 male ASD patients with high normal or intermediate allele showed a normal pattern indicating the FMR1 promoter unmethylated allele (Supplementary Figure 2). These 3 ASD patients and their mothers had at least one AGG interruption (Supplementary Figure 3). The presence of AGG interruptions in the CGG repeats of the FMR1 gene reduces repeat instability during transmission from parent to child and decreases the risk of CGG expansion during maternal transmission. In our study, mothers who carried high normal or intermediate CGG alleles did not show the increase of CGG repeat expansions in their children. When we compared the high normal and intermediate CGG repeats (range: $41-54$ repeats) in the male ASD cases with the male controls using Fisher's exact test, we still did not find a statistically significant difference $(P=0.3255)$. The frequency of intermediate alleles (defined as 45-54 repeats) in our ASD patients was approximately $1 \%$ $(2 / 202)$. No premutations or full mutations were identified in either the ASD or normal control groups in the study.

\section{Discussion}

ASD is a group of complex neurodevelopment disorders with multiple etiologies. Among the genetic causes, mutations in the FMR1 gene, which cause FXS, are the leading known genetic cause of autism. Diagnosis of individuals with ASD and FXS is difficult due to overlapping symptoms. Given the possibility of an ASD-FXS link, it is now recommended that all individuals with ASD should be referred for genetic evaluation and testing for FXS when the etiology of their autism is not known [5, 9]. FXS is caused by an expanded number of CGG repeats ( $>200$ repeats) in the $5^{\prime}$ UTR of the FMR1 gene leading to a deficiency or absence of FMRP, an RNA-binding protein that regulates the translation of a number of other genes that are important for synaptic development and plasticity. Many of these genes, including neuroligins, neurorexin 1, PTEN, PSD95, MAPK1, JAKMIP, SHANK3, and CYFIP1, are linked to autism when they are mutated $[7,8,15,66]$, which may explain the high comorbidity that exists between FXS and ASD. The rates of comorbid diagnosis of FXS and ASD greatly differ across the literature. The frequency of autism among males with FXS varies widely, from $18.5 \%$ in the first estimate by Brown et al. [67] and ranging from $5 \%$ to $60 \%$ in subsequent studies depending on the diagnostic criteria and methodologies used for DNA testing. However, FXS is rarely found in autism individuals who have had full clinical evaluation [17, 20-25].

The present study was aimed at screening for CGG repeat expansion in the FMR1 gene among a group of Thai patients with nonsyndromic ASD. No premutation or full mutation alleles were found in this cohort, which is comparable to other studies done in Indonesia, Japan, Australia, and the USA [53-56, 68]. Several studies published in the last decade have reported FXS full mutations in approximately $0-6 \%$ of ASD patients [33-56] (Table 2). The rates of FMR1 expansion among ASD patients vary widely across studies, depending on different factors including ethnic background, small sample sizes in various studies, possibility of referral bias, diagnostic criteria for autism, and method of FXS diagnosis. The discrepancies regarding the prevalence of FXS among individuals with autism may reflect the limited reliability of the cytogenetic tests used in the past compared with the more sensitive molecular tests currently used. Regarding the prevalence of FXS, there is the possibility that 


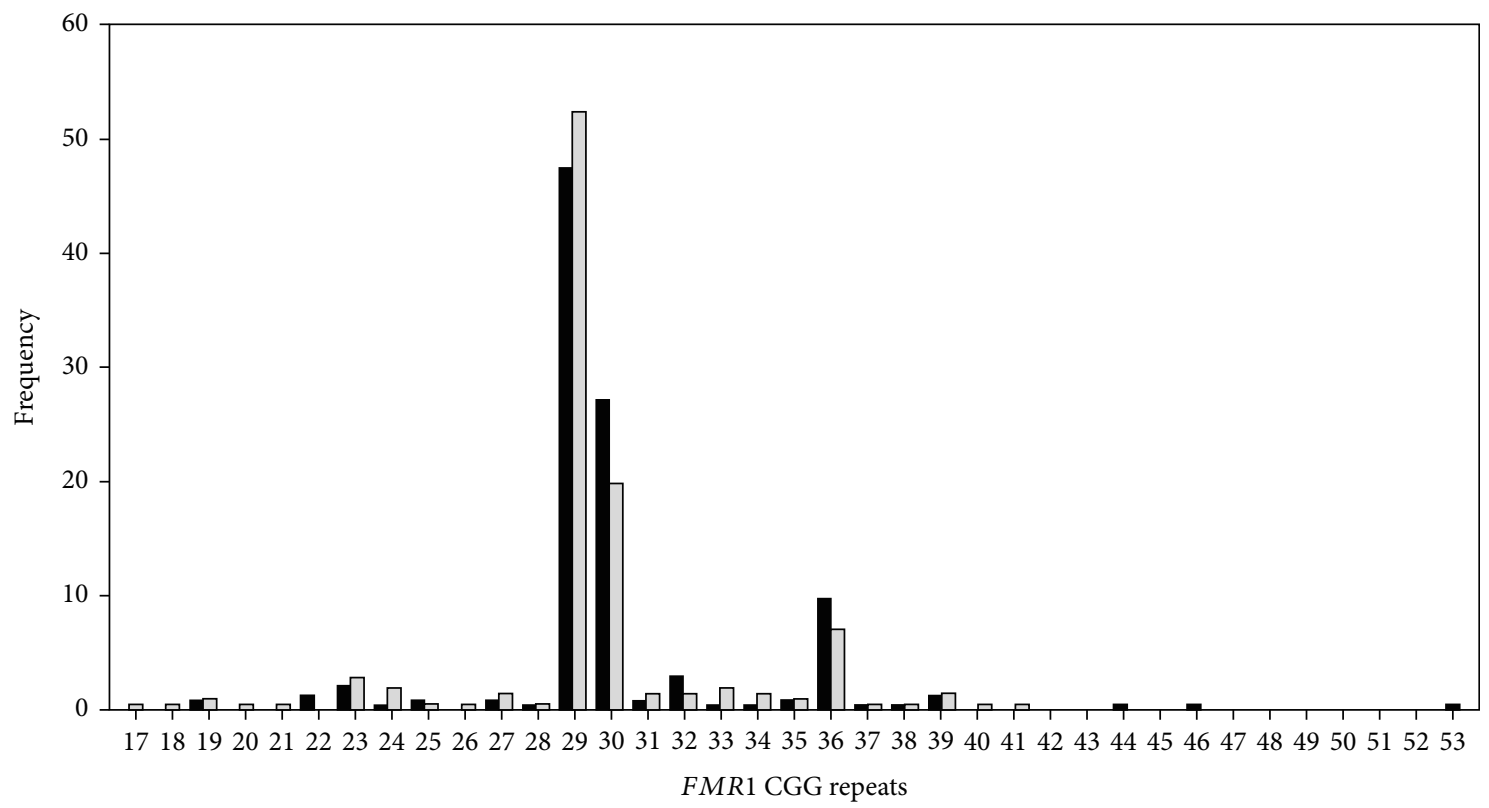

ASD patients

$\square$ Normal controls

Figure 1: Distribution of FMR1 CGG alleles in the study of ASD patients ( $n=202 ; 168$ males and 34 females) and normal Thai controls ( $n=212$ males). The most common alleles in the Thai population are 29 and 30 CGG repeats, followed by 36 repeats.

founder effects could result in some populations having higher prevalences of FXS. Although FXS affects all ethnic groups, the prevalence may vary between populations. A previous study reported that the incidence of FXS in countries with significant Asian populations was significantly lower than that in Western countries [69].

In our study, two ASD patients with intermediate alleles were detected, yielding an intermediate allele frequency of $\sim 1 \%(2 / 202)$, which was consistent with reports in ASD patients in other populations in Italy [43] and the USA countries $[47,51,52]$. In comparing CGG repeats with a normal Thai control group, 3 ASD patients showed high normal or intermediate CGG repeat alleles, with 44, 46, and 53 CGG repeats, while these alleles were absent in the normal male controls. All three patients had delayed speech development, mild ID, and hyperactivity. The FMR1 intermediate alleles may show some instability and may expand into the premutation range when transmitted by the mother $[70,71]$. Previous studies have reported that $7.7 \%$ of parents with FMR1 alleles in the $40-49$ repeat range and $25 \%$ of parents with FMR1 alleles in the 50-60 repeat range were more likely to pass a changed number of FMR1 CGG repeats to their children [72]. An intermediate allele expanding to a full mutation over two generations was reported in a family where a 44 or 52 CGG maternal grandfather transmitted a full mutation to his grandson [73, 74]. The impact of alleles on intermediate CGG number is not well understood, and there are various definitions of "intermediate allele." The American College of Medical Genetics and Genomics (ACMG) practice guidelines (2005) defined CGG repeats from 41-60 as the intermediate or gray zone [75], but the recent ACMG standards and guidelines for FXS testing changed the definition of intermediate or gray zone to 4554 [10]. However, some population studies have used 4154 repeats $[53,76,77]$. These discrepancies in the definition of the intermediate alleles have become more important because several studies have now reported phenotypes associated with the FMR1 gray zone or intermediate allele. A previous study found elevated mRNA levels in intermediate alleles and premutation alleles with a lower threshold of normal CGG repeats (5-40 CGG) [78]. Based on this finding, intermediate alleles may be similar to premutation alleles which are known to be associated with some neurodevelopmental conditions and late-onset tremor ataxia (FXTAS) [79-87]. Consistent with earlier reports, we found some increase of intermediate alleles in ASD subjects compared with the controls, although the differences were nonsignificant. Some studies have reported significantly increased frequencies of intermediate alleles in individuals with autism, ID, and learning difficulties compared with normal controls [56, 88-91]; however, other studies had different findings [51, 53, 92-95]. A high frequency of intermediate alleles has also been associated with an increased risk for some behavioral phenotypes, including autistic behavior, developmental delay, and learning disabilities [84-87, 91], although such associations are uncertain as they have been based on only a few small studies. Intermediate alleles have also been identified in females with premature ovarian failure, females with Parkinsonism, and individuals with symptoms of the late-onset neurodegenerative disorder, FXTAS [79-83, 86, 87]. Despite the small sample size of the current study, our results support the hypothesis that intermediate alleles of the FMR1 gene might be associated with autism $[56,84$, $85,91]$, but further studies are required with larger numbers 
TABLE 2: Review of the literature on fragile X syndrome screening in ASD patients. Only studies that performed molecular techniques for fragile X testing are included.

\begin{tabular}{|c|c|c|c|c|c|}
\hline $\begin{array}{l}\text { Country/ } \\
\text { region }\end{array}$ & Study subjects & $\begin{array}{l}\text { Instrument(s) used } \\
\text { for ASD diagnosis }\end{array}$ & $\begin{array}{l}\text { Method(s) for } \\
\text { FXS testing }\end{array}$ & Main findings & References \\
\hline \multicolumn{6}{|c|}{ Asian countries } \\
\hline China & $\begin{array}{l}73 \mathrm{ID}, \mathrm{DD}, \mathrm{ADHD} \\
\mathrm{ASD}(28 \mathrm{ASD})\end{array}$ & NA & SB & Premutation: $1.4 \%(1 / 73)$ & Chan and Wong [33] \\
\hline China & 143 ASD patients & DSM-III-R & PCR & $\begin{array}{l}\text { Intermediate, premutation, full } \\
\text { mutation: } 0 \%(0 / 143)\end{array}$ & Poon et al. [95] \\
\hline China & 177 ASD patients & NA & PCR & $\begin{array}{l}\text { Premutation, full mutation: } \\
4.5 \%(8 / 177)\end{array}$ & Wang et al. [34] \\
\hline Japan & 109 ASD patients & $\begin{array}{l}\text { DSM-IV } \\
\text { ICD-10 }\end{array}$ & $\begin{array}{l}\text { PCR with CE } \\
\text { SB }\end{array}$ & $\begin{array}{l}\text { Intermediate, premutation, full } \\
\text { mutation: } 0 \%(0 / 109)\end{array}$ & Otsuka et al. [53] \\
\hline Indonesia & $\begin{array}{l}144 \text { patients } \\
\text { (i) } 32 \mathrm{ASD} \\
\text { (ii) } 112 \mathrm{ID}\end{array}$ & NA & $\begin{array}{l}\text { PCR with CE } \\
\text { SB }\end{array}$ & $\begin{array}{l}\text { Full mutation: } 0.7 \%(1 / 144) \\
\text { (i) ASD: } 0 \%(0 / 32) \\
\text { (ii) ID: } 0.9 \%(1 / 112)\end{array}$ & Winarni et al. [54] \\
\hline Indonesia & 65 ASD patients & $\begin{array}{l}\text { DSM-IV-TR } \\
\text { CARS }\end{array}$ & $\begin{array}{l}\text { Cytogenetics } \\
\text { PCR } \\
\text { SB }\end{array}$ & Full mutation: $6.15 \%(4 / 65)$ & Winarni et al. [35] \\
\hline Korea & 66 ASD patients & $\begin{array}{l}\text { DSM-IV } \\
\text { CARS }\end{array}$ & SB & $\begin{array}{l}\text { Premutation: } 7.6 \%(5 / 66) \\
\text { Full mutation and mosaic mutation: } \\
1.5 \%(1 / 66)\end{array}$ & Kang et al. [36] \\
\hline Korea & $\begin{array}{l}101 \text { patients } \\
\text { (i) } 31 \mathrm{ASD} \\
\text { (ii) } 63 \mathrm{ID} \\
\text { (iii) } 7 \mathrm{LD}\end{array}$ & NA & $\begin{array}{l}\text { Cytogenetics } \\
\text { PCR } \\
\text { SB }\end{array}$ & Full mutation: $1 \%(1 / 101)$ & Kwon et al. [37] \\
\hline Sri Lanka & $\begin{array}{l}850 \text { patients } \\
\text { (i) } 135 \text { ASD } \\
\text { (ii) } 112 \text { ADHD } \\
\text { (iii) } 603 \text { physical and } \\
\text { behavioral } \\
\text { disorders }\end{array}$ & NA & $\begin{array}{l}\text { PCR with CE } \\
\text { MCA } \\
\text { (FastFraX } \\
\text { FMR1 kit) } \\
\text { MS-PCR } \\
\text { SB }\end{array}$ & $\begin{array}{l}\text { (i) Intermediate: } 0.1 \%(1 / 850) \\
\text { (ii) Premutation: } 0.8 \%(7 / 850) \\
\text { (iii) Full mutation: } 1.3 \%(11 / 850) \\
\text { (4 ASD, } 3 \text { ADHD, } \\
4 \text { physical and behavioral } \\
\text { disorders) }\end{array}$ & Chandrasekara et al. [38] \\
\hline Thailand & $\begin{array}{l}202 \text { ASD patients } \\
\text { (168 males, } 34 \\
\text { females) }\end{array}$ & DSM-IV & $\begin{array}{l}\text { PCR with CE } \\
\text { MS-PCR } \\
\text { SB }\end{array}$ & $\begin{array}{l}\text { (i) Intermediate: } 1 \%(2 / 202) \\
\text { (ii) Premutation, full mutation: } 0 \% \\
(0 / 202)\end{array}$ & This study \\
\hline
\end{tabular}

Non-Asian countries (Australia, European, South American, North American)

\begin{tabular}{|c|c|c|c|c|c|}
\hline $\begin{array}{l}\text { Australia } \\
\text { (Tasmania) }\end{array}$ & $\begin{array}{l}1,248 \mathrm{ID}, \mathrm{ADHD} \\
\text { ASD }\end{array}$ & NA & $\begin{array}{l}\text { PCR } \\
\text { SB }\end{array}$ & $\begin{array}{l}\text { (i) Intermediate* }: 3.4 \%(43 / 1,248) \\
\text { (ii) Premutation, full mutation: } 0 \% \\
(0 / 1,248)\end{array}$ & Mitchell et al. [56] \\
\hline Australia & $\begin{array}{l}16 \text { ASD patients** } \\
\text { (fragile X testing) }\end{array}$ & DSM-IV-TR & $\begin{array}{l}\text { PCR } \\
\text { SB }\end{array}$ & Full mutation: $1.2 \%(2 / 167)$ & Mordaunt et al. [39] \\
\hline Brazil & 83 ASD patients & NA & PCR with CE & $\begin{array}{l}\text { (i) Intermediate: } 4.8 \%(4 / 83) \\
\text { (ii) Premutation: } 4.8 \%(4 / 83) \\
\text { (iii) Full mutation: } 0 \%(0 / 83)\end{array}$ & Ferreira et al. [40] \\
\hline Canada & $\begin{array}{l}2,486 \mathrm{ID}, \mathrm{DD} \\
\mathrm{ASD}^{* *}\end{array}$ & NA & NA & $\begin{array}{l}\text { (i) Premutation: } 0.4 \%(10 / 2,486) \\
\text { (ii) Full mutation and mosaic } \\
\text { mutation: } 1.2 \%(30 / 2,486)\end{array}$ & Borch et al. [41] \\
\hline France & $\begin{array}{l}312 \text { ASD patients** } \\
\text { (fragile X testing) }\end{array}$ & $\begin{array}{l}\text { DSM } \\
\text { ADOS } \\
\text { CARS } \\
\text { ADI-R }\end{array}$ & NA & Full mutation: $1.3 \%(4 / 312)$ & Munnich et al. [42] \\
\hline
\end{tabular}


TABLE 2: Continued.

\begin{tabular}{|c|c|c|c|c|c|}
\hline $\begin{array}{l}\text { Country/ } \\
\text { region }\end{array}$ & Study subjects & $\begin{array}{l}\text { Instrument(s) used } \\
\text { for ASD diagnosis }\end{array}$ & $\begin{array}{l}\text { Method(s) for } \\
\text { FXS testing }\end{array}$ & Main findings & References \\
\hline Italy & $\begin{array}{l}\text { 2,850 patients } \\
\text { (i) } 2,750 \text { ID, DD, } \\
\text { hyperactivity } \\
\text { (ii) } 82 \text { ASD } \\
\text { (iii) } 18 \text { POI }\end{array}$ & NA & $\begin{array}{l}\text { PCR with CE } \\
\text { TP-PCR } \\
\text { AmplideX }{ }^{\mathrm{TM}} \\
\text { FMR1 kit } \\
\text { SB }\end{array}$ & $\begin{array}{l}\text { Intermediate: } 0.5 \%(13 / 2,850) \\
\text { Premutation: } 2.9 \%(83 / 2,850) \\
\text { (i) ID, DD: } 2.8 \%(77 / 2,750) \\
\text { (ii) ASD: } 0 \%(0 / 82) \\
\text { (iii) POI: } 33.3 \%(6 / 18) \\
\text { Full mutation: } 2.9 \%(82 / 2,850) \\
\text { (i) ID, DD: } 2.9 \%(81 / 2,750) \\
\text { (ii) ASD: } 1.2 \%(1 / 82) \\
\text { (iii) POI: } 0 \%(0 / 18)\end{array}$ & Esposito et al. [43] \\
\hline Israel & $\begin{array}{l}59 \text { ASD patients } \\
\text { (fragile X testing) }\end{array}$ & $\begin{array}{l}\text { DSM-IV } \\
\text { CARS }\end{array}$ & $\begin{array}{c}\text { Cytogenetics } \\
\text { SB }\end{array}$ & Full mutation: $3.4 \%(2 / 59)$ & Kosinovsky et al. [44] \\
\hline Spain & 206 ASD patients & DSM-V & $\begin{array}{l}\text { PCR with CE } \\
\text { (Asuragen } \\
\text { AmplideX } \\
\text { kit PCR/CE } \\
\text { FMR1) }\end{array}$ & Full mutation: $1 \%(2 / 206)$ & Arteche-López et al. [45] \\
\hline Sweden & $\begin{array}{l}142 \text { ASD patients } \\
\text { (fragile X testing) }\end{array}$ & $\begin{array}{l}\text { DSM-IV } \\
\text { ABC }\end{array}$ & NA & Full mutation: $0.7 \%(1 / 142)$ & Eriksson et al. [46] \\
\hline USA & 316 ASD patients & NA & $\begin{array}{l}\text { Cytogenetics } \\
\text { PCR } \\
\text { SB }\end{array}$ & $\begin{array}{l}\text { (i) Intermediate: } 2.2 \%(7 / 316) \\
\text { (ii) Premutation: } 0.3 \%(1 / 316) \\
\text { (iii) Full mutation and mosaic } \\
\text { mutation: } 1.9 \%(6 / 316)\end{array}$ & Reddy [47] \\
\hline USA & $\begin{array}{l}861 \text { ASD patients** } \\
\text { (fragile X testing) }\end{array}$ & DSM-IV-TR & NA & $\begin{array}{l}\text { (i) Premutation: } 0.2 \%(2 / 861) \\
\text { (ii) Full mutation and mosaic } \\
\text { mutation: } 0.2 \%(2 / 861)\end{array}$ & Shen et al. [48] \\
\hline USA & $\begin{array}{l}183 \text { ASD patients** } \\
\text { (fragile X testing) }\end{array}$ & DSM-IV & NA & $\begin{array}{l}\text { Premutation: } 1.1 \%(2 / 183) \\
\text { Full mutation: } 0.5 \%(1 / 183)\end{array}$ & Roesser [49] \\
\hline USA & $\begin{array}{l}174 \text { ASD patients** } \\
\text { (fragile X testing) }\end{array}$ & $\begin{array}{l}\text { ADOS } \\
\text { ABC } \\
\text { CARS } \\
\text { GARS } \\
\text { DSM-IV }\end{array}$ & NA & Full mutation: $0.6 \%(1 / 174)$ & McGrew et al. [50] \\
\hline USA & $\begin{array}{l}599 \text { patients } \\
\text { (i) } 453 \text { autism/ASD } \\
\text { (ii) } 146 \mathrm{DD}\end{array}$ & $\begin{array}{l}\text { ADI-R } \\
\text { ADOS }\end{array}$ & $\begin{array}{c}\text { PCR with CE } \\
\text { TP-PCR }\end{array}$ & $\begin{array}{l}\text { (i) Intermediate: } 1.3 \%(8 / 599) \\
\text { (7 autism/ASD, 1 DD) } \\
\text { (ii) Premutation: } 0.3 \%(2 / 599) \\
\text { (2 DD) } \\
\text { (iii) Full mutation: } 0.7 \%(4 / 599) \\
\text { (2 autism, } 2 \text { DD) }\end{array}$ & Tassone et al. [51] \\
\hline USA & $\begin{array}{l}75 \text { ASD patients } \\
\text { (fragile X testing) }\end{array}$ & NA & $\begin{array}{l}\text { PCR with CE } \\
\text { TP-PCR }\end{array}$ & Full mutation: $0 \%(0 / 75)$ & Weinstein et al. [55] \\
\hline USA & 299 ASD patients & DSM-V & $\begin{array}{l}\text { PCR with CE } \\
\text { (Asuragen } \\
\text { AmplideX } \\
\text { kit PCR/CE } \\
\text { FMR1) }\end{array}$ & $\begin{array}{l}\text { (i) Intermediate: } 0.7 \%(2 / 299) \\
\text { (ii) Premutation: } 1 \%(3 / 299) \\
\text { (iii) Full mutation and mosaic } \\
\text { mutation: } 1.3 \%(4 / 299)\end{array}$ & Harris et al. [52] \\
\hline
\end{tabular}

${ }^{*}$ 41-60 repeats; ** retrospective chart review. ASD: autism spectrum disorder; ABC: Autistic Behavior Checklist; ADOS: Autism Diagnostic Observation Schedule; ADI-R: Autism Diagnostic Interview-Revised; ADHD: attention deficit hyperactivity disorder; CE: capillary electrophoresis; DD: developmental delay; DSM: Diagnostic and Statistical Manual of Mental Disorders; GARS: Gilliam Autism Rating Scale; ID: intellectual disability; MCA: melting curve analysis; NA: not available; POI: Primary ovarian insufficiency; SB: southern blot analysis.

of cases and controls from the Thai population and other different ethnic groups to confirm that intermediate alleles can be a risk factor of autism.

The CGG repeat distribution has been reported to vary widely among different populations [69]. In Thailand, this study reported the distributions of CGG alleles to be similar in both ASD and normal control groups. The most common alleles in our study group were 29 and 30 repeats, followed by 36 CGG repeats, which are the same frequencies as previously reported in the Indonesian, Chinese, Korean, and Thai populations in previous reports [58, 96-98]. The 29 and 30 CGG repeats are also the most common numbers found in Caucasian populations, but the 30 repeats are present at a higher frequency than the 29 repeats, which is different from 
Asian populations [69]. In contrast, a study in Japanese patients found 27,26 , and 28 to be the most common alleles [53]. In some Mexican subpopulations, 32 and 30 were the most frequent repeat numbers [99].

According to the American College of Medical Genetics and Genomics and the American Academy of Pediatrics, the first-tier genetic tests for individuals with ASD, DD, and/or ID include chromosomal microarray and fragile $\mathrm{X}$ testing [9, 29-32]. Moreover, several studies have suggested that the diagnostic yield of fragile $\mathrm{X}$ syndrome and chromosomal microarray combined with next-generation sequencing was significantly higher than that of fragile $\mathrm{X}$ syndrome and/or microarray alone $[42,45]$. Due to the limitations of the methods commonly used for FXS diagnosis, we were unable to detect other uncommon causes of FXS including point mutations, deletions, and duplications which can also affect FMR1 expression and FMRP level; however, during the FXS testing in our study, some available DNA samples of the patients in this cohort were also evaluated using SNP microarray and whole exome sequencing to look for point mutations, deletions, and duplications of the FMR1 gene and other genes that may be associated with ASD in patients. During preparation of this research article, of the 202 ASD patients, SNP microarray was performed for 65 of them, and 9 patients were found to have pathogenic copy number variations (CNVs) or variants of uncertain significance (VOUS), likely pathogenic CNVs [100]. Whole exome sequencing was performed on 11 ASD patients, and two patients carrying clinically significant variants were identified [101, 102]. However, no point mutation, deletion, and duplication of the FMR1 gene were detected in these patients. Our results and review of the literature support the recommendation that fragile $\mathrm{X}$ testing should be included as part of initial genetic testing in patients receiving a diagnosis of ASD. We also recommend that the combined genetic testing of FMR1 testing, chromosomal microarray, and/or whole exome sequencing should be performed to increase the diagnostic yield of ASD.

\section{Conclusion}

This study reports for the first time the frequency of the FXS mutation in ASD patients in Thailand. Although no FMR1 premutations or full mutations were found, the study identified high normal and intermediate alleles in three ASD patients while these alleles were absent in the normal controls. Our findings add weight to the evidence that intermediate alleles may be considered as indicating an increased risk for autism; however, further studies with larger samples of ASD cases and controls from different ethnic groups are required to further elucidate the role of intermediate alleles in the etiology of autism and other neurodevelopmental disorders. The causes of ASD could involve multiple genes and other factors, and efforts should be made to identify the causes of ASD in this group of patients. FXS may be less common in children being clinically diagnosed with ASD in the Thai population; thus, we cannot conclude from this study that the FMR1 gene is a susceptible genetic factor in Thai autistic patients. The data from this study should pro- vide a foundation for further investigations of FXS in Thai patients with ASD.

\section{Data Availability}

All the data used to support the findings of this study are included within the article and the supplementary information file.

\section{Conflicts of Interest}

All authors declare that they have no conflicts of interest.

\section{Authors' Contributions}

PL and AH designed the study and wrote the manuscript. CJ performed mutation screening. AH performed confirmation of FMR1 high normal and intermediate alleles in ASD patients and their mothers. All authors reviewed and approved the final manuscript.

\section{Acknowledgments}

We would like to thank Dr. Thanya Sripo, Ms. Supaporn Yangngam, and Ms. Oradawan Plong-On for the technical assistance. We also thank the following pediatricians for sample recruitment: Drs. Juthamas Worachotekamjorn, Tippawan Hansakunachai, Rawiwan Roongpraiwan, Tasnawat Sombuntham, and Nichara Ruangdaraganon. We thank Dr. Chariyawan Charalsawad for the suggestion in manuscript writing and Mr. David Patterson for English language editing. This work was supported by the National Center for Genetic Engineering and Biotechnology (BIOTEC) grant no. BT-B-01-MG-18-4814 and grants from the Faculty of Medicine, Prince of Songkla University.

\section{Supplementary Materials}

Supplementary Table 1: CGG repeat genotypes of the FMR1 gene in ASD females. Supplementary Figure 1: fluorescent PCR fragment analysis showing 31 and 53 CGG repeats in the mother and 53 CGG repeats in the ASD son. Supplementary Figure 2: methylation-specific PCR results. Lane 1: $100 \mathrm{bp}$ marker, lane 2: normal male control showing a FMR1 promoter unmethylated band and an XIST promoter methylated band, lane 3: full mutation male (positive control) showing a FMR1 promoter methylated band and an XIST promoter methylated band, lane 4: ASD male with 44 CGG repeats, lane 5: ASD male with 46 CGG repeats, lane 6: ASD male with 53 CGG repeats, lane: 7 normal female control, and lane 8: no template DNA. Supplementary Figure 3: electropherogram of TP-PCR for FMR1 CGG expanded alleles and AGG interruptions. Mothers of male patients carrying high normal or intermediate CGG alleles had at least one AGG interruption: (A) full mutation female (positive control) showing serial peak; (B) female with 29 and 44 CGG repeats: 44 repeat alleles having one AGG interruption; (C) female with 29 and 46 CGG repeats: 46 repeat alleles having one AGG interruption. Superimposed closeup electropherogram shows the end of continuous stutter 
peaks of 46 repeats allele. (D) Female with 31 and 53 CGG repeats: 53 repeats allele having four AGG interruptions. CGG repeats are based on the fluorescent PCR results. In heterozygous females, AGG interruption patterns can only be determined in larger repeat alleles because it is difficult to correctly identify AGG patterns in lower repeats alleles. (Supplementary Materials)

\section{References}

[1] M. J. Maenner, K. A. Shaw, J. Baio et al., "Prevalence of autism spectrum disorder among children aged 8 Years Autism and developmental disabilities monitoring network, 11 sites, United States, 2016," MMWR Surveillance Summaries, vol. 69, no. 4, pp. 1-12, 2020.

[2] A. Ronald and R. A. Hoekstra, "Autism spectrum disorders and autistic traits: a decade of new twin studies," American Journal of Medical Genetics Part B Neuropsychiatric Genetics, vol. 156, no. 3, pp. 255-274, 2011.

[3] I. Iossifov, M. Ronemus, D. Levy et al., "De novo gene disruptions in children on the autistic spectrum," Neuron, vol. 74, no. 2, pp. 285-299, 2012.

[4] G. Huguet, E. Ey, and T. Bourgeron, "The genetic landscapes of autism spectrum disorders," Annual Review of Genomics and Human Genetics, vol. 14, no. 1, pp. 191-213, 2013.

[5] B. A. Fernandez and S. W. Scherer, "Syndromic autism spectrum disorders: moving from a clinically defined to a molecularly defined approach," Dialogues in Clinical Neuroscience, vol. 19, no. 4, pp. 353-371, 2017.

[6] S. Kumar, K. Reynolds, Y. Ji, R. Gu, S. Rai, and C. J. Zhou, "Impaired neurodevelopmental pathways in autism spectrum disorder: a review of signaling mechanisms and crosstalk," Journal of Neurodevelopmental Disorders, vol. 11, no. 1, pp. 1-14, 2019.

[7] L. Rylaarsdam and A. Guemez-Gamboa, "Genetic causes and modifiers of autism spectrum disorder," Frontiers in Cellular Neuroscience, vol. 13, no. 385, pp. 1-15, 2019.

[8] A. Havdahl, M. Niarchou, A. Starnawska, M. Uddin, C. van der Merwe, and V. Warrier, "Genetic contributions to autism spectrum disorder," Psychological Medicine, vol. 51, no. 13, pp. 2260-2273, 2021.

[9] G. B. Schaefer, N. J. Mendelsohn, and Professional Practice and Guidelines Committee, "Clinical genetics evaluation in identifying the etiology of autism spectrum disorders: 2013 guideline revisions," Genetics in Medicine, vol. 15, no. 5, pp. 399-407, 2013.

[10] E. Spector, A. Behlmann, K. Kronquist et al., "Laboratory testing for fragile X, 2021 revision: a technical standard of the American College of Medical Genetics and Genomics (ACMG)," Genetics in Medicine, vol. 23, no. 5, pp. 799-812, 2021.

[11] S. L. Nolin, W. T. Brown, A. Glicksman et al., "Expansion of the fragile X CGG repeat in females with premutation or intermediate alleles," American Journal of Human Genetics, vol. 72, no. 2, pp. 454-464, 2003.

[12] C. M. Yrigollen, B. Durbin-Johnson, L. Gane et al., "AGG interruptions within the maternal_FMR1_ gene reduce the risk of offspring with fragile X syndrome," Genetics in Medicine, vol. 14, no. 8, pp. 729-736, 2012.

[13] A. McDuffie, A. J. Thurman, R. J. Hagerman, and L. Abbeduto, "Symptoms of autism in males with fragile X syndrome: a comparison to nonsyndromic ASD using current ADI-R scores," Journal of Autism and Developmental Disorders, vol. 45, no. 7, pp. 1925-1937, 2015.

[14] A. Movaghar, D. Page, D. Scholze et al., "Artificial intelligence-assisted phenotype discovery of fragile X syndrome in a population-based sample," Genetics in Medicine, vol. 23, no. 7, pp. 1273-1280, 2021.

[15] T. W. Yu and E. Berry-Kravis, "Autism and fragile X syndrome," Seminars in Neurology, vol. 34, no. 3, pp. 258-265, 2014.

[16] M. Lee, G. E. Martin, E. Berry-Kravis, and M. Losh, “A developmental, longitudinal investigation of autism phenotypic profiles in fragile X syndrome," Journal of Neurodevelopmental Disorders, vol. 8, no. 1, pp. 1-20, 2016.

[17] W. E. Kaufmann, S. A. Kidd, H. F. Andrews et al., "Autism spectrum disorder in fragile X syndrome: cooccurring conditions and current treatment," Pediatrics, vol. 139, Supplement 3, pp. S194-S206, 2017.

[18] J. E. Roberts, J. E. Ezell, A. J. Fairchild et al., "Biobehavioral composite of social aspects of anxiety in young adults with fragile X syndrome contrasted to autism spectrum disorder," American Journal of Medical Genetics Part B Neuropsychiatric Genetics, vol. 177, no. 7, pp. 665-675, 2018.

[19] R. Hagerman, S. Rivera, and P. Hagerman, "The fragile X family of disorders: a model for autism and targeted treatments," Current Pediatric Reviews, vol. 4, no. 1, pp. 40-52, 2008.

[20] W. E. Kaufmann, R. Cortell, A. S. M. Kau et al., "Autism spectrum disorder in fragile $\mathrm{X}$ syndrome: communication, social interaction, and specific behaviors," American Journal of Medical Genetics Part A, vol. 129A, no. 3, pp. 225-234, 2004.

[21] S. Clifford, C. Dissanayake, Q. M. Bui, R. Huggins, A. K. Taylor, and D. Z. Loesch, "Autism spectrum phenotype in males and females with fragile X full mutation and premutation," Journal of Autism and Developmental Disorders, vol. 37, no. 4, pp. 738-747, 2007.

[22] S. W. Harris, D. Hessl, B. Goodlin-Jones et al., "Autism profiles of males with fragile X syndrome," American Journal on Mental Retardation, vol. 113, no. 6, pp. 427-438, 2008.

[23] D. B. Bailey, M. Raspa, E. Bishop, and D. Holiday, "No change in the age of diagnosis for fragile $\mathrm{x}$ syndrome: findings from a national parent survey," Pediatrics, vol. 124, no. 2, pp. 527-533, 2009.

[24] J. Klusek, G. E. Martin, and M. Losh, "Consistency between research and clinical diagnoses of autism among boys and girls with fragile X syndrome," Journal of Intellectual Disability Research, vol. 58, no. 10, pp. 940-952, 2014.

[25] E. Haebig, A. Sterling, A. Barton-Hulsey, and L. Friedman, "Rates and predictors of co-occurring autism spectrum disorder in boys with fragile X syndrome," Autism \& Developmental Language Impairments, vol. 5, article 239694152090532, 2020.

[26] A. Bailey, P. Bolton, L. Butler et al., "Prevalence of the fragile $\mathrm{X}$ anomaly amongst autistic twins and singletons," Journal of Child Psychology and Psychiatry, vol. 34, no. 5, pp. 673-688, 1993.

[27] M. M. Mazzocco, W. R. Kates, T. L. Baumgardner, L. S. Freund, and A. L. Reiss, "Autistic behaviors among girls with fragile X syndrome," Journal of Autism and Developmental Disorders, vol. 27, no. 4, pp. 415-435, 1997. 
[28] A. C. Wheeler, J. Mussey, A. Villagomez et al., "DSM-5 changes and the prevalence of parent-reported autism spectrum symptoms in fragile X syndrome," Journal of Autism and Developmental Disorders, vol. 45, no. 3, pp. 816-829, 2015.

[29] D. T. Miller, M. P. Adam, S. Aradhya et al., "Consensus statement: chromosomal microarray is a first-tier clinical diagnostic test for individuals with developmental disabilities or congenital anomalies," American Journal of Human Genetics, vol. 86, no. 5, pp. 749-764, 2010.

[30] K. G. Monaghan, E. Lyon, and E. B. Spector, "ACMG standards and guidelines for fragile $\mathrm{X}$ testing: a revision to the disease-specific supplements to the Standards and Guidelines for Clinical Genetics Laboratories of the American College of Medical Genetics and Genomics," Genetics in Medicine, vol. 15, no. 7, pp. 575-586, 2013.

[31] American College of Obstetricians and Gynecologists Committee on Genetics, ACOG Committee Opinion No 469, "Carrier screening for fragile X syndrome," Obstetrics \& Gynecology, vol. 116, no. 4, pp. 1008-1010, 2010.

[32] S. L. Hyman, S. E. Levy, S. M. Myers, and Council on Children With Disabilities, Section on Developmental and Behavioral Pediatrics, "Identification, evaluation, and management of children with autism spectrum disorder," Pediatrics, vol. 145, no. 1, article e20193447145, pp. 1-64, 2020.

[33] S. Y. Chan and V. Wong, "DNA diagnosis of FRAXA and FRAXE in Chinese children with neurodevelopmental disorders and fragile X syndrome," Clinical Genetics, vol. 53, no. 3, pp. 179-183, 1998.

[34] X. Wang, M. Hou, D. Zhang, and N. Zhong, "Molecular screening of FMR1 mutation among autism patients in China," World Journal of Pediatrics, vol. 2, no. 4, pp. 285287, 2006.

[35] T. I. Winarni, A. Utari, F. E. P. Mundhofir, R. J. Hagerman, and S. M. H. Faradz, "Fragile X syndrome: clinical, cytogenetic and molecular screening among autism spectrum disorder children in Indonesia," Clinical Genetics, vol. 84, no. 6, pp. 577-580, 2013.

[36] K. M. Kang, D. I. Kwak, and M. S. Lee, "Molecular genetic study for FMR-1 gene in autistic children," Journal of Korean Neuropsychiatric Association, vol. 38, no. 6, pp. 1479-1487, 1999.

[37] S. H. Kwon, K. S. Lee, M. C. Hyun, K. E. Song, and J. K. Kim, "Molecular screening for fragile X syndrome in mentally handicapped children in Korea," Journal of Korean Medical Science, vol. 16, no. 3, pp. 271-275, 2001.

[38] B. Chandrasekara, S. Wijesundera, S. S. Chong, and H. N. Perera, "Prevalence of fragile X syndrome among children receiving special education and carrier states in first degree relatives," Ceylon Medical Journal, vol. 62, no. 2, pp. 92-96, 2017.

[39] D. Mordaunt, M. Gabbett, M. Waugh, K. O'Brien, and H. Heussler, "Uptake and diagnostic yield of chromosomal microarray in an Australian child development clinic," Children, vol. 1, no. 1, pp. 21-30, 2014.

[40] J. F. B. Ferreira, J. S. Batista, and C. Fantin, "Screening for FMR1 expanded alleles in patients with autism spectrum disorders in Manaus, northern Brazil," Anais da Academia Brasileira de Ciencias, vol. 91, no. 3, pp. 1-6, 2019.

[41] L. A. Borch, J. Parboosingh, M. A. Thomas, and P. Veale, "Reevaluating the first-tier status of fragile $\mathrm{X}$ testing in neurode- velopmental disorders," Genetics in Medicine, vol. 22, no. 6, pp. 1036-1039, 2020.

[42] A. Munnich, C. Demily, L. Frugère et al., "Impact of on-site clinical genetics consultations on diagnostic rate in children and young adults with autism spectrum disorder," Molecular Autism, vol. 10, no. 1, pp. 1-10, 2019.

[43] G. Esposito, R. Ruggiero, G. Savarese et al., “A 15-year casemix experience for fragile $\mathrm{X}$ syndrome molecular diagnosis and comparison between conventional and alternative techniques leading to a novel diagnostic procedure," Clinica Chimica Acta, vol. 417, pp. 85-89, 2013.

[44] B. Kosinovsky, S. Hermon, R. Yoran-Hegesh et al., "The yield of laboratory investigations in children with infantile autism," Journal of Neural Transmission, vol. 112, no. 4, pp. 587-596, 2005.

[45] A. Arteche-López, M. J. Gómez Rodríguez, M. T. Sánchez Calvin et al., "Towards a change in the diagnostic algorithm of autism spectrum disorders: evidence supporting whole exome sequencing as a first-tier test," Genes, vol. 12, no. 4, p. 560, 2021.

[46] M. A. Eriksson, A. Liedén, J. Westerlund et al., "Rare copy number variants are common in young children with autism spectrum disorder," Acta Paediatrica, vol. 104, no. 6, pp. 610618, 2015.

[47] K. S. Reddy, "Cytogenetic abnormalities and fragile-X syndrome in autism spectrum disorder," BMC Medical Genetics, vol. 6, no. 1, pp. 1-16, 2005.

[48] Y. Shen, K. A. Dies, I. A. Holm et al., "Clinical genetic testing for patients with autism spectrum disorders," Pediatrics, vol. 125, no. 4, pp. e727-e735, 2010.

[49] J. Roesser, "Diagnostic yield of genetic testing in children diagnosed with autism spectrum disorders at a regional referral center," Clinical Pediatrics, vol. 50, no. 9, pp. 834-843, 2011.

[50] S. G. McGrew, B. R. Peters, J. A. Crittendon, and J. VeenstraVanderweele, "Diagnostic yield of chromosomal microarray analysis in an autism primary care practice: which guidelines to implement?," Journal of Autism and Developmental Disorders, vol. 42, no. 8, pp. 1582-1591, 2012.

[51] F. Tassone, N. S. Choudhary, F. Tassone et al., "Identification of expanded alleles of the FMR1 gene in the CHildhood Autism Risks from Genes and Environment (CHARGE) study," Journal of Autism and Developmental Disorders, vol. 43, no. 3, pp. 530-539, 2013.

[52] H. K. Harris, G. D. Sideridis, W. J. Barbaresi, and E. Harstad, "Pathogenic yield of genetic testing in autism spectrum disorder," Pediatrics, vol. 146, no. 4, article e20193211, pp. e20193211-e20193219, 2020.

[53] S. Otsuka, Y. Sakamoto, H. Siomi et al., "Fragile X carrier screening and _FMR1_ allele distribution in the Japanese population," Brain and Development, vol. 32, no. 2, pp. 110-114, 2010.

[54] T. I. Winarni, A. Utari, F. E. P. Mundhofir et al., "Identification of expanded alleles of the FMR1 gene among high-risk population in Indonesia by using blood spot screening," Genetic Testing and Molecular Biomarkers, vol. 16, no. 3, pp. 162-166, 2012.

[55] V. Weinstein, P. Tanpaiboon, K. A. Chapman, N. Ah Mew, and S. Hofherr, "Do the data really support ordering fragile $\mathrm{X}$ testing as a first-tier test without clinical features?," Genetics in Medicine, vol. 19, no. 12, pp. 1317-1322, 2017. 
[56] R. J. Mitchell, J. J. Holden, C. Zhang et al., "FMR1 alleles in Tasmania: a screening study of the special educational needs population," Clinical Genetics, vol. 67, no. 1, pp. 38-46, 2005.

[57] J. M. Savatt and S. M. Myers, "Genetic testing in neurodevelopmental disorders," Frontiers in Pediatrics, vol. 9, no. 526779, pp. 1-24, 2021.

[58] P. Limprasert, N. Ruangdaraganon, T. Sura, P. Vasiknanonte, and U. Jinorose, "Molecular screening for fragile X syndrome in Thailand," Southeast Asian Journal of Tropical Medicine and Public Health, vol. 30, Supplement 2, pp. 114-118, 1999.

[59] C. Charalsawadi, W. Maisrikhaw, V. Praphanphoj et al., "A case with a ring chromosome 13 in a cohort of 203 children with non-syndromic autism and review of the cytogenetic literature," Cytogenetic and Genome Research, vol. 144, no. 1, pp. 1-8, 2014.

[60] T. Hansakunachai, R. Roongpraiwan, T. Sombuntham, P. Limprasert, and N. Ruangdaraganon, "A new structured interview for children with autism spectrum disorder based on the DSM-IV," Journal of the Medical Association of Thailand, vol. 97, Supplement 8, pp. S7-14, 2014.

[61] S. Yangngam, O. Plong-On, T. Sripo et al., "Mutation screening of the neurexin 1 gene in Thai patients with intellectual disability and autism spectrum disorder," Genetic Testing and Molecular Biomarkers, vol. 18, no. 7, pp. 510-515, 2014.

[62] F. Tassone, R. Pan, K. Amiri, A. K. Taylor, and P. J. Hagerman, "A Rapid Polymerase Chain Reaction-Based Screening Method for Identification of All Expanded Alleles of the Fragile X (FMR1) Gene in Newborn and High-Risk Populations," Journal of Molecular Diagnostics, vol. 10, no. 1, pp. 43-49, 2008.

[63] F. M. Hantash, D. G. Goos, D. Tsao et al., "Qualitative assessment of FMR1 (CGG)n triplet repeat status in normal, intermediate, premutation, full mutation, and mosaic carriers in both sexes: implications for fragile $\mathrm{X}$ syndrome carrier and newborn screening," Genetics in Medicine, vol. 12, no. 3, pp. 162-173, 2010.

[64] E. Lyon, T. Laver, P. Yu et al., "A simple, high-throughput assay for Fragile $\mathrm{X}$ expanded alleles using triple repeat primed PCR and capillary electrophoresis," Journal of Molecular Diagnostics, vol. 12, no. 4, pp. 505-511, 2010.

[65] C. Charalsawadi, T. Sripo, and P. Limprasert, "Multiplex methylation specific PCR analysis of fragile X syndrome: experience in Songklanagarind Hospital," Journal of the Medical Association of Thailand, vol. 88, no. 8, pp. 1057-1061, 2005.

[66] R. Hagerman, G. Hoem, and P. Hagerman, "Fragile X and autism: intertwined at the molecular level leading to targeted treatments," Molecular Autism, vol. 1, no. 1, pp. 12-14, 2010.

[67] W. T. Brown, E. C. Jenkins, E. Friedman et al., "Autism is associated with the fragile-X syndrome," Journal of Autism and Developmental Disorders, vol. 12, no. 3, pp. 303-308, 1982.

[68] S. V. Mullegama, S. D. Klein, D. C. Nguyen et al., "Is it time to retire fragile $\mathrm{X}$ testing as a first-tier test for developmental delay, intellectual disability, and autism spectrum disorder?," Genetics in Medicine, vol. 19, no. 1380, pp. 1-2, 2017.

[69] E. Peprah, "Fragile X syndrome: the FMR1 CGG repeat distribution among world populations," Annals of Human Genetics, vol. 76, no. 2, pp. 178-191, 2012.

[70] S. L. Nolin, A. Glicksman, X. Ding et al., "Fragile X analysis of 1112 prenatal samples from 1991 to 2010," Prenatal Diagnosis, vol. 31, no. 10, pp. 925-931, 2011.
[71] S. L. Nolin, A. Glicksman, N. Tortora et al., "Expansions and contractions of the FMR1 CGG repeat in 5,508 transmissions of normal, intermediate, and premutation alleles," American Journal of Medical Genetics Part A, vol. 179, no. 7, pp. 1148-1156, 2019.

[72] S. L. Nolin, Lewis FA 3rd, L. L. Ye et al., "Familial transmission of the FMR1 CGG repeat," American Journal of Human Genetics, vol. 59, no. 6, pp. 1252-1261, 1996.

[73] A. Terracciano, M. G. Pomponi, G. M. E. Marino et al., "Expansion to full mutation of a_FMR1_intermediate allele over two generations," European Journal of Human Genetics, vol. 12, no. 4, pp. 333-336, 2004.

[74] I. Fernandez-Carvajal, B. Lopez Posadas, R. Pan, C. Raske, P. J. Hagerman, and F. Tassone, "Expansion of an _FMR1_ Grey-Zone Allele to a Full Mutation in Two Generations," Journal of Molecular Diagnostics, vol. 11, no. 4, pp. 306310, 2009.

[75] S. Sherman, B. A. Pletcher, and D. A. Driscoll, "Fragile X syndrome: diagnostic and carrier testing," Genetics in Medicine, vol. 7, no. 8, pp. 584-587, 2005.

[76] F. Tassone, K. P. Iong, T.-H. Tong et al., "FMR1 CGG allele size and prevalence ascertained through newborn screening in the United States," Genome Medicine, vol. 4, no. 12, p. 100, 2012.

[77] M. M. Seltzer, M. W. Baker, J. Hong, M. Maenner, J. Greenberg, and D. Mandel, "Prevalence of CGG expansions of the FMR1 gene in a US population-based sample," American Journal of Medical Genetics Part B, vol. 159B, no. 5, pp. 589-597, 2012.

[78] D. Z. Loesch, Q. M. Bui, R. M. Huggins, R. J. Mitchell, R. J. Hagerman, and F. Tassone, "Transcript levels of the intermediate size or grey zone fragile $\mathrm{X}$ mental retardation 1 alleles are raised, and correlate with the number of CGG repeats," Journal of Medical Genetics, vol. 44, no. 3, pp. 200-204, 2007.

[79] B. Bodega, S. Bione, L. Dalprà et al., "Influence of intermediate and uninterrupted FMR1 CGG expansions in premature ovarian failure manifestation," Human Reproduction, vol. 21, no. 4, pp. 952-957, 2006.

[80] K. L. Bretherick, M. R. Fluker, and W. P. Robinson, "FMR1 repeat sizes in the gray zone and high end of the normal range are associated with premature ovarian failure," Human Genetics, vol. 117, no. 4, pp. 376-382, 2005.

[81] A. K. Sullivan, M. Marcus, M. P. Epstein et al., "Association of FMR1 repeat size with ovarian dysfunction," Human Reproduction, vol. 20, no. 2, pp. 402-412, 2005.

[82] D. A. Hall, S. Nag, B. Ouyang et al., "Fragile X gray zone alleles are associated with signs of parkinsonism and earlier death," Movement Disorders, vol. 35, no. 8, pp. 1448-1456, 2020.

[83] D. A. Hall, E. Berry-Kravis, W. Zhang et al., "FMR1 grayzone alleles: association with Parkinson's disease in women?" Movement Disorders, vol. 26, no. 10, pp. 1900-1906, 2011.

[84] M. Aziz, E. Stathopulu, M. Callias et al., "Clinical features of boys with fragile X premutations and intermediate alleles," American Journal of Medical Genetics Part B Neuropsychiatric Genetics, vol. 121B, no. 1, pp. 119-127, 2003.

[85] D. Z. Loesch, D. E. Godler, M. Khaniani et al., "Linking the FMR1 alleles with small CGG expansions with neurodevelopmental disorders: preliminary data suggest an involvement of epigenetic mechanisms," American Journal of Medical Genetics Part A, vol. 149A, no. 10, pp. 2306-2310, 2009. 
[86] D. A. Hall, "In the gray zone in the fragile $\mathrm{X}$ gene: what are the key unanswered clinical and biological questions?," Tremor and Other Hyperkinetic Movements, vol. 4, no. 208, pp. 1-7, 2020.

[87] S. M. Debrey, M. A. Leehey, O. Klepitskaya et al., "Clinical phenotype of adult fragile $\mathrm{X}$ gray zone allele carriers: a case series," Cerebellum, vol. 15, no. 5, pp. 623-631, 2016.

[88] A. Murray, S. Youings, N. Dennis et al., "Population screening at the FRAXA and FRAXE loci: molecular analyses of boys with learning difficulties and their mothers," Human Molecular Genetics, vol. 5, no. 6, pp. 727-735, 1996.

[89] L. A. Haddad, M. J. Aguiar, S. S. Costa, R. C. Mingroni-Netto, A. M. Vianna-Morgante, and S. D. Pena, "Fully mutated and gray-zone FRAXA alleles in Brazilian mentally retarded boys," American Journal of Medical Genetics, vol. 84, no. 3, pp. 198-201, 1999.

[90] S. A. Youings, A. Murray, N. Dennis et al., "FRAXA and FRAXE: the results of a five year survey," Journal of Medical Genetics, vol. 37, no. 6, pp. 415-421, 2000.

[91] M. Shekari Khaniani, F. Amini Yeganeh, S. Amiri, and S. Mansouri Derakhshan, "Autistic phenotype of permutation and intermediate alleles of FMR1 gene," Iranian Journal of Pediatrics, vol. 27, no. 4, article e9445, pp. 1-5, 2017.

[92] E. Mornet, C. Chateau, B. Simon-Bouy, and J. L. Serre, "The intermediate alleles of the fragile X CGG repeat in patients with mental retardation," Clinical Genetics, vol. 53, no. 3, pp. 200-201, 1998.

[93] D. C. Crawford, K. L. Meadows, J. L. Newman et al., "Prevalence and phenotype consequence of FRAXA and FRAXE alleles in a large, ethnically diverse, special education-needs population," American Journal of Human Genetics, vol. 64, no. 2, pp. 495-507, 1999.

[94] P. C. Patsalis, C. Sismani, J. A. Hettinger et al., "Frequencies of "grey-zone" and premutation-size FMR1 CGG-repeat alleles in patients with developmental disability in Cyprus and Canada," American Journal of Medical Genetics, vol. 84, no. 3, pp. 195-197, 1999.

[95] P. M. Poon, Q. L. Chen, K. Y. Lai, C. K. Wong, and C. P. Pang, "CGG repeat interruptions in the FMR1 gene in patients with infantile autism," Clinical Chemistry and Laboratory Medicine, vol. 36, no. 8, pp. 649-653, 1998.

[96] J.-H. Jang, K. Lee, E.-H. Cho, E.-H. Lee, J.-W. Kim, and C.S. Ki, "Frequency of FMR1 premutation carriers and rate of expansion to full mutation in a retrospective diagnostic FMR1 Korean sample," Clinical Genetics, vol. 85, no. 5, pp. 441-445, 2014.

[97] S. M. H. Faradz, M. Z. Pattiiha, D. A. Leigh et al., "Genetic diversity at the FMR1 locus in the Indonesian population," Annals of Human Genetics, vol. 64, no. 4, pp. 329-339, 2000.

[98] Y. Zhou, K. Tang, H.-Y. Law, I. S. L. Ng, C. G. L. Lee, and S. S. Chong, "FMR1 CGG repeat patterns and flanking haplotypes in three Asian populations and their relationship with repeat instability," Annals of Human Genetics, vol. 70, no. 6, pp. 784-796, 2006.

[99] P. Barros-Núñez, M. A. Rosales-Reynoso, L. Sandoval, P. Romero-Espinoza, R. Troyo-Sanromán, and B. Ibarra, "Genetic variation of the FMR1 gene among four Mexican populations: Mestizo, Huichol, Purepecha, and Tarahumara," American Journal of Human Biology, vol. 20, no. 3, pp. 259263, 2008.
[100] A. Hnoonual, W. Thammachote, T. Tim-Aroon et al., "Chromosomal microarray analysis in a cohort of underrepresented population identifies SERINC2 as a novel candidate gene for autism spectrum disorder," Scientific Reports, vol. 7, no. 12096, pp. 1-11, 2017.

[101] A. Hnoonual, T. Sripo, and P. Limprasert, "Whole-exome sequencing identifies a novel heterozygous missense variant of the EN2 gene in two unrelated patients with autism spectrum disorder," Psychiatric Genetics, vol. 26, no. 6, pp. 297$301,2016$.

[102] A. Hnoonual, P. Graidist, S. Kritsaneepaiboon, and P. Limprasert, "Novel compound heterozygous mutations in the TRAPPC9 gene in two siblings with autism and intellectual disability," Frontiers in Genetics, vol. 10, no. 61, pp. 1-7, 2019. 